\title{
CORPO E SIMBOLISMO NA DOAÇÃO DE ÓRGÃOS, UMA INTRODUÇÃO
}

\author{
Body and symbolism in organ donation, an introduction
}

\author{
Viviane Fernandes
}

\section{RESUMO}

Pensar em doação de órgãos é inseparável da compreensão do que é o corpo para a sociedade a partir da qual se pensa, porque o corpo é símbolo da sociedade e nele são refletidas as incongruências sócio-culturais. A doação de órgãos liga-se a um conjunto de significados que desperta sentimentos, que impelem a ação humana e a legitimam. Pensar sobre o tema possibilita o entendimento e a reflexão sobre o nosso próprio corpo e o posicionamento diante da temática. É importante o potencial de novo significado do corpo, da morte, da vida no contexto da doação de órgãos.

Descritores: Corpo; Morte; Doação de Órgãos.

\section{Instituição:}

Programa de Pós-Graduação em Saúde e Ambiente Universidade Tiradentes - Aracaju/SE

\section{Correspondência:}

Viviane Fernandes

Av. Murilo Dantas, 300. Bloco F. PSA - CEP 49032-490 - Aracaju/SE

Tel.: (79) $32182115 \quad$ (79) 991001009

E-mail: vivianefernandes@doarse.com

Recebido em: 06/03/2014

Aceito em: $31 / 03 / 3014$

\section{INTRODUÇÃO}

Inicio as reflexões sobre a relação corpo e sociedade valendo-me das formulações de José Carlos Rodrigues (1983), apresentadas em seu livro "Tabu do Corpo".

Segundo esse autor, a sociedade privilegia um dado número de características e atributos que deve ter o homem, sejam morais, intelectuais ou físicas. Esses atributos são, basicamente, os mesmos para toda a sociedade, embora possam ter diferentes nuances para determinados grupos, classes ou categorias que fazem parte da sociedade. De acordo com Rodrigues “(...) como qualquer outra realidade do mundo, o corpo humano é socialmente concebido, e ... a análise da representação social do corpo oferece uma das numerosas vias de acesso à estrutura de uma sociedade particular." 2 
O corpo humano, para além de seu caráter biológico, é afetado pela religião, grupo familiar, nível social, cultura e outras intervenções sociais. Assim, cumpre uma função ideológica, isto é, as escolhas funcionam como garantia ou não da integridade de uma pessoa, em termos de grau de proximidade ou de afastamento em relação ao conjunto de atributos que caracterizam a imagem dos indivíduos em relação às tipificações. É assim que, em função das aparências (atributos físicos), alguém é considerado como um indivíduo capaz ou não de cometer uma transgressão (atributos morais), por exemplo. Isso significa que o corpo está investido de crenças e sentimentos que estão na origem da vida social, mas que, ao mesmo tempo, não estão submetidas ao corpo: "O mundo das representações se adiciona e se sobrepõe a seu fundamento natural e material, sem provir diretamente dele". ${ }^{3}$ Também, segundo esse mesmo autor, o corpo funciona como marca dos valores sociais e nele a sociedade fixa seus sentidos e valores.

Socialmente, o corpo é dado como um signo e fica claro que não tem limites a sua utilidade como sistema de expressão. Daí o fato de as culturas privilegiarem determinadas partes do corpo em detrimento de outras, a existência de inúmeras assertivas com relação aos órgãos e partes do corpo. Como por exemplo, a simbologia associada ao coração e a relação entre o lado esquerdo do corpo para mal e o direito para o bem, privilegiando assim a mão e o pé direitos.

Quando o indivíduo explicita à sua família sua vontade de ser ou não um doador de órgãos, ou mesmo quando doa um de seus órgãos duplos ou medula a um familiar ou amigo, expressa através dessas atitudes o reflexo das suas concepções, crenças e sua visão de mundo, que são construídas socialmente, e que lhe fornecem as bases para tomar qualquer atitude com relação ao seu corpo. Tenho por base a definição semiótica de cultura definida por Geertz, que a percebe com uma teia de significados à qual o homem se vê amarrado. A cultura percebida como um sistema de símbolos impõe ao antropólogo a difícil tarefa de interpretá-la.

Nem sempre os antropólogos têm plena consciência desse fato: que embora a cultura exista no posto comercial, no forte da colina ou no pastoreio de carneiros, a antropologia existe no livro, no artigo, na conferência, na exposição do museu ou, como ocorre hoje, nos filmes. Convencer-se disso é compreender que a linha entre o modo de representação e o conteúdo substantivo é tão não-traçável na análise cultural, como é na pintura. E esse fato, por sua vez, parece ameaçar o status objetivo do conhecimento antropológico, sugerindo que sua fonte não é a realidade social, mas um artifício erudito. ${ }^{4}$

Nessa perspectiva, a prática da doação de órgãos pode ser tomada como um texto cultural passível de múltiplas interpretações. Essa reflexão propõe-se a ser apenas uma entre tantas interpretações possíveis desse fenômeno sociocultural.

O clássico da Antropologia chamado "Pureza e Perigo", da antropóloga norte-americana Mary Douglas, faz uma reflexão sobre os sentidos e conexões entre pureza, poluição e perigo em "sociedades primitivas", o que nos ajuda a pensar em nossa sociedade sobre as noções de pureza ou impureza associadas ao processo de doação de órgãos. Especialmente no capítulo VII, denominado Fronteiras Exteriores, a autora trabalha a ideia de sociedade como uma imagem poderosa, capaz de dominar os homens e motivá-los à ação. Essa imagem tem forma, possuindo uma estrutura interna, regiões marginais e fronteiras exteriores. Nos limites, encontra-se o poder de repelir a agressão e recompensar o conformismo. As experiências que os seres humanos têm nesses três distintos espaços da imagem que possuímos da sociedade são um reservatório de símbolos da sociedade.

O corpo humano, mais diretamente que o do animal, é matéria de simbolismo. É o modelo por excelência de todo o sistema finito. Os seus limites podem representar as fronteiras ameaçadas ou precárias. Como o corpo tem uma estrutura complexa, as funções e as relações entre as suas diferentes partes podem servir de símbolos a outras estruturas complexas. ${ }^{6}$

Parece impossível compreender o conjunto das representações sociais a respeito da doação de órgãos, se for ignorado que o corpo é símbolo da sociedade e reproduz em pequena escala, os poderes e os perigos atribuídos à estrutura social.

Mary Douglas defende que, quando em uma sociedade, comportamentos, ações, ideias, categorias sociais, instituições são ordenados, são também classificados como puros ou impuros, de modo que o perigo da desestabilização social seja evitado. Nesse sentido, o grau de organização e de estabilidade de uma sociedade reflete o nível de consenso e legitimidade alcançado pela ordenação e hierarquização de experiências, puras ou impuras, em si mesmas não unitárias, inerentemente desordenadas. Neste ponto, o pensamento de Douglas permite compreender que, realmente, nossa sociedade ainda não atingiu um bom ou alto grau de estabilidade e organização, para poder refletirse em um também alto nível de consenso e legitimidade pela organização e hierarquização das experiências. Sim, pois é verificável a caracterização de impureza também na doação de órgãos, pois quando muitas pessoas, inclusive não apenas leigos, pessoas do próprio sistema de saúde denominam a equipe da Central de Transplantes de "papadefuntos", numa conotação de negatividade, de não apoio ao trabalho realizado.

Dessa forma, utilizo esse referencial teórico para verificar a existência de associação à pureza ou impureza na doação 
de órgãos. O puro, o poluído e o perigoso são classificações simbólicas, atribuídas a práticas sociais e situações que fazem sentido para o sistema social estabelecido, e legitimam a ordem hierárquica, o poder de arbítrio de instituições e dos sujeitos que as representam de fato e de direito, e que por isso são hegemônicos.

Por conseguinte, segundo Douglas, não há pureza ou impureza absoluta. Elas existem aos olhos de quem as vê, podendo arbitrar e constituir verdade. Por outro lado, para Mary Douglas, não há nada de amedrontador ou irracional em identificar algo de impuro: é um movimento criativo, um esforço para relacionar forma e função das coisas, ideias e sentimentos, fazer da experiência uma unidade, uma vez que o próprio corpo, com suas necessidades, doenças, as impressões mais variadas das coisas, sensações ou emoções, diferenciações entre sagrado ou profano, é uma realidade movediça que precisa ser coletivamente orientada. Isto se aplica perfeitamente ao discurso da maioria dos entrevistados, pois acreditam que doar é uma grande decisão de caráter até sublime, poderíamos dizer atitude de grande "pureza", seguida de uma sensação de perigo diante da insegurança, e dos medos motivados na maioria das situações devido à ausência de informações, ignorância do processo ou pelo tipo de atendimento no serviço de saúde.

O imaginário é uma importante representação para compreender as posições diante do tema em foco. Ele permite uma construção que não corresponde necessariamente em todos os aspectos à realidade, mas que tem alguma conexão com ela. A estratégia do imaginário é tão somente deslocar o "estímulo perceptual", ou seja, a apreensão da realidade, de tal maneira a criar "novas relações inexistentes no real". Por ser uma representação simbólica, o imaginário trabalha com construção de símbolos, que é a atribuição de significados, a ideia representativa de um dado da realidade. Entretanto, por serem fruto da imaginação, os símbolos construídos pelo imaginário não exigem comprovação, comparação ou verificação com o real. Quando representamos a doação de órgãos, é aos símbolos que nos referimos sempre, não à própria realidade em si; são imagens e representações mentais que podem não ser a doação em si, mas que falam por ela, como a morte, a vida, o procedimento cirúrgico, etc.

A doação de órgãos liga-se a um conjunto de significados, despertando sentimentos que impelem à ação humana e a legitimam. Os símbolos evocam também diferentes olhares e entendimentos diversos, pois mobiliza a subjetividade das emoções. Um mesmo símbolo pode suscitar orgulho em um e desprezo em outro, mas ambos estarão amparados por uma realidade comum representada.

“[...] os símbolos sãopolissêmicos e polivalentes, aparando-se também no referencial significante que lhes propicia os sentidos, os quais contêm significações afetivas e são mobilizadores de comportamentos sociais. A eficácia dos símbolos consiste nesse caráter mobilizador e promotor das experiências cotidianas: os símbolos permitem a cura de doenças psicossomáticas e fazem emergir emoções como: raiva, violência, nostalgia e euforia. ${ }^{8}$

Essa polissemia e polivalência simbólica abrem espaço para uma disputa de poder para associar determinados sentimentos a determinados símbolos representativos.

Douglas (1991) e Turner (1974) compartilharam o mesmo pensamento ao dizer que algumas ideias sociais não podem ser expressas sem uma forma: o símbolo. - Turner utilizase da ideia de símbolos multivocais, ou seja, passíveis de muitos significados. ${ }^{3,5}$

Esses são canais de comunicação entre e intra-grupos, representações coletivas que ajudam a levantar a parte temporal da estrutura social - uma relação entre posições, funções e cargos sociais - e não algo localizado no inconsciente, como coloca LÉVI-STRAUSS, responsável pela ordem implícita neste sistema. ${ }^{6}$

Há muito ainda a ser desmistificado e incorporado ao imaginário da nossa sociedade sobre essa temática. Mas, é preciso destacar o potencial de ressignificação cultural do corpo, da morte e da vida, no contexto da doação de órgãos. Nesse contexto, a morte pode passar a ser interpretada como possibilidade de vida para outro; a vida ganha outras significações devido à possibilidade de o corpo, enquanto instrumento poder ser útil, mesmo após o fatídico fim. A vida que finda à espera por um órgão cheia de limitações e em contagem regressiva, absurdamente sentida e vista via corpo, ressurge com a possibilidade do transplante. Senão qual fênix mitológica, mas com toda a esperança de mais realizações na vida. Afinal, é no limite, ou situação de liminaridade, conforme Turner (1974), que as potências significadoras e ressignificadoras apresentam-se de forma mais pungente.

\section{AGRADECIMENTOS}

Gratidão à Professora Eufrázia Cristina Menezes Santos pelo incentivo à pesquisa antropológica nos meus primeiros passos na temática. Aos que fazem a Central de Transplantes de Sergipe, especialmente à Professora Emília Cervino Nogueira e a Benito Fernandez, pelo compromisso com a causa. Ao Programa Saúde e Ambiente|UNIT e os atuais orientadores, Professores Francisco Prado Reis e Sônia Oliveira Lima pelo acolhimento ao projeto. À Capes/CNPq, pela bolsa que tornou possível a continuidade, junto à temática, de maneira integral. 
Corpo e simbolismo na doação de órgãos, uma introdução.

\section{ABSTRACT}

Thinking about organ donation is inseparable from the understanding of what is the body for the society from which one thinks, since the body is a symbol of the society, reflecting its social-cultural inconsistencies. Organ donation is linked to a set of meanings that arouses feelings that drive human action and legitimate them. Thinking about it allows the understanding and reflection on our own body and the positioning on such matter. It is important to the body's reframing potential, death, and life within the context of the organ donation.

Keywords: Body; Death; Tissue; Organ Donation.

\section{REFERÊNCIAS}

1 Rodrigues J C. Tabu do corpo. Rio de Janeiro: Achiamé;1983.

2 Geertz C A interpretação das culturas. Rio de Janeiro: Guanabara; 1989.

3 Douglas M. Pureza e perigo: perspectivas do homem. Rio de Janeiro: Edições 70; 1991.
4 Laplantine F, Trindade LS. O Que é Imaginário. São Paulo: Brasiliense; 2003.

5 Turner V. Processo Ritual. Petrópolis: Vozes; 1974.

6 Lévi-Strauss C. Antropologia Estrutural. 6a ed. Rio de Janeiro: Tempo Brasileiro; 2003. 